\title{
Implementasi Metode Kombinasi Histogram Of Oriented Gradients Dan Hierarchical Centroid Untuk Sketch Based Image Retrieval
}

\author{
Atika Faradina Randa, Nanik Suciati, Dini Adni Navastara \\ Jurusan Teknik Informatika, Fakultas Teknologi Informasi, Institut Teknologi Sepuluh Nopember (ITS) \\ Jl. Arief Rahman Hakim, Surabaya 60111 Indonesia \\ e-mail:nanik@if.its.ac.id
}

\begin{abstract}
Abstrak-Teknik pencarian gambar yang saat ini umum digunakan masih berbasis teks atau text based search seperti pada mesin pencarian Google Image, Yahoo, dan lain sebagainnya. Namun metode ini masih kurang efektif karena nama dari sebuah file tidak dapat merepresentasikan isinya, oleh karena itu diperlukan pemilihan kata kunci yang benar-benar tepat agar hasil yang diinginkan dapat ditampilkan dengan baik. Salah satu teknik pencarian gambar yang saat ini sedang diteliti adalah Sketch-Based Image Retrieval (SBIR). Dengan teknik ini user dapat menginputkan sketsa gambar atau user dapat menggambarkan obyek pada area yang disediakan lalu sistem akan melakukan pencocokkan sketsa dengan database gambar. Untuk mengimplementasikan teknik ini digunakan metode kombinasi Histogram of Oriented Gradient dan Hierarchical Centroid. Tahapan implementasi teknik tersebut yaitu, yang pertama melakukan preprocessing pada gambar dengan cara mendeteksi tepi obyek lalu membuat citra menjadi hitam putih. Yang kedua melakukan ektraksi fitur menggunakan Histogram of Oriented Gradients dan Hierarchical Centroid dan menghasilkan fitur vektor. Yang terakhir menghitung jarak kedekatan antara gambar yang diuji dengan gambar yang terdapat dalam database menggunakan Euclidean Distance. Hasil Euclidean Distance kemudian diurutkan secara ascending dan dikembalikan sejumlah gambar yang jaraknya terdekat. Hasil temu kembali menghasilkan nilai Average Normalized Modified Retrieval Rank sebesar 0,35 dan nilai presisi dan recall sebesar $78 \%$ dan akurasi sebesar $96 \%$.
\end{abstract}

Kata Kunci-Sketch Base Image Retrieval, Histogram of Oriented Gradients, Hierarchical Centroid, Average Normalized Modified Ratrieval Rank

\section{PENDAHULUAN}

$\mathrm{P}$ ENELITIAN image retrieval pada awalnya dilakukan dengan berbasis teks dari citra yang akan dicari. Seperti pada halnya mesin pencarian gambar seperti Google Images, Yahoo, dan lain-lain masih menggunakan metode berbasis teks atau text-based search yaitu mengembalikan citra yang sesuai dengan kata kunci yang dimasukkan [1]. Dengan kompleksitas informasi yang dimiliki oleh suatu citra user tidak berharap mendapatkan kecocokkan dengan pasti antara queri atau kata kunci yang dimasukkan dan citra yang akan ditampilkan kembali dari database. Untuk itu teknik pencarian gambar berbasis teks ini belum sepenuhnya efektif karena nama dari sebuah file tidak dapat merepresentasikan isinya. Oleh karena itu diperlukan pemilihan kata kunci yang benar-benar tepat agar hasil yang diinginkan dapat ditampilkan. Untuk mengatasi masalah tersebut diperlukan pendekatan alternatif. Penelitian tentang image retrieval sudah banyak dilakukan. Salah satunya yang sedang populer adalah menggunakan queri berupa citra hasil jepretan kamera. Dengan metode seperti itu membutuhkan kompleksitas waktu dan komputasi yang besar.

Content Based Image Retrieval (CBIR) bertujuan untuk mempermudah dan mempercepat pencarian informasi bersarkan pada informasi citra dari citra yang mirip dengan kriteria tertentu yang diinginkan dari sekumpulan image yang ada. Karekteristik yang dihasilkan berupa bentuk, warna, tekstur dan lain-lain sesuai dengan citra yang diinginkan. Salah satu perkembangan Content Based Image Retrieval yaitu Sketch Based Image Retrieval. Dengan Sketch Based Image Retrieval (SBIR) user dapat menggambarkan obyek pada area yang telah disediakan lalu sistem akan mencocokkan sketsa dengan database. Penggunaan queri dengan sketsa ini dapat sangat berguna dan efisien pada kehidupan sehari-hari, karena user dapat mengingat kembali suatu obyek dengan bantuan sketsa dari obyek tersebut. Teknologi SBIR dapat berguna diberbagai bidang seperti mengidentifikasi pelaku kejahatan dari sketsa wajahnya, mengidentifikasi bentuk tato, grafiti, lukisan dan lain sebagiannya. Image retrieval dengan sketsa ini penelitiannya masih jarang dilakukan dari pada metode CBIR yang telah memiliki variasi deskriptor untuk mendapatkan fitur [2]. Ada beberapa penelitian yang telah dilakukan sebelumnya yaitu menggunakan Query by Visual Example (QVE) yang menggunakan edge map sebagai sketsa citra dan citra tes dipetakan dalam representasi yang abstrak. Proses ini membutuhkan dana yang banyak dan masih belum didukung oleh banyak software [3]. Metode yang lain yaitu dengan melakukan pendekatan dari bentuk citra. Pendekatan tersebut ternyata memberikan hasil yang bagus [4] dengan menggabungkan metode Histogram of Oriented Gradient dan Hierarchical Centroid [5]. Dengan banyaknya kegunaan dari teknik SBIR ini maka topik tugas akhir ini akan menerapkan teknik tersebut dengan metode Histogram of Oriented Gradient dan Hierarchical Centroid.

Oleh karena itu untuk menyelesaikan permasalahan tersebut, pada tugas akhir ini akan dimplementasikan metode kombinasi Histogram of Oriented Gradients dan Hierarchical Centroid (HOG-HC). Teknik yang dilakukan yaitu melakukan preprocessing dengan cara membuat citra menjadi hitam putih lalu mendeteksi bagian tepi dari citra. Setelah didapatkan citra hasil preprocessing lalu dilakukan ekstraksi fitur menggunakan metode HOG-HC dan selanjutnya menghitung jarak kedekatan 
menggunakan euclidean distance dan mengembalikkan citra yang jaraknya terdekat.

\section{METODE}

\section{A. Histogram of Oriented Gradients (HOG)}

Dari berbagai penelitian menunjukkan bahwa metode HOG cocok dijadikan deskriptor untuk pencarian gambar berbasis sketsa [6]. Metode HOG banyak digunakan pada computer vision. HOG adalah deskriptor berbasis window yang mendeteksi pada titik interest. Metode ini menghitung nilai gradien dalam daerah tertentu pada suatu citra. Setiap citra memiliki karakteristik yang ditunjukkan oleh distribusi gradien yang diperoleh dengan membagi citra ke dalam daerah kecil yang disebut cell. Tiap cell disusun dari sebuah histogram dari sebuah gradien. Kombinasi dari histogram ini dijadikan sebagai deskriptor yang mewakili sebuah obyek [7]. Diagram alir algoritma HOG dapat dilihat pada Gambar 1.

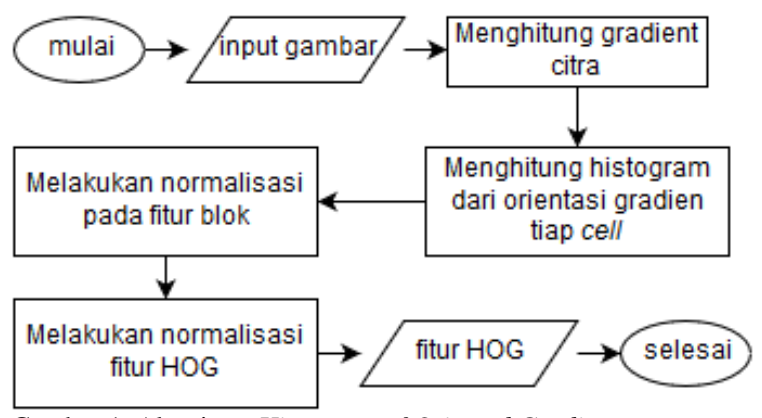

Gambar 1. Algoritma Histogram of Oriented Gradients

Dari Gambar 1, tahap awal dari metode HOG adalah menghitung nilai gradien citra dihitung menggunakan (1).

$$
|G|=\sqrt{I_{x}^{2}+I_{y}^{2}}
$$

Dimana $I$ adalah citra graylevel. $I_{x}$ merupakan matrik terhadap sumbu- $x$ dan $I_{y}$ merupakan matrik terhadap sumbu-y. $I_{x}$ dan $I_{y}$ dapat dihitung dengan (2).

$$
I_{x}=I * D_{x}, \quad I_{y}=I * D_{y}
$$

$D_{x}$ adalah mask $\left[\begin{array}{lll}-1 & 0 & 1\end{array}\right]$, sedangkan $D_{y}$ adalah mask $\left[\begin{array}{c}-1 \\ 0 \\ 1\end{array}\right]$

masing-masing dihitung dengan cara konvolusi. Kemudian gradien ditransformasi ke dalam kordinat sumbu dengan sudut diantara 0 sampai $180^{\circ}$ yang disebut orientasi gradien. Orientasi gradien $(\theta)$ dapat dihitung dengan (3).

$$
\theta=\arctan \left(\frac{I_{x}}{I_{y}}\right)
$$

Tahap selanjutnya adalah melakukan perhitungan histogram dari orientasi gradien tiap cell. Setiap piksel dalam sebuah cell mempunyai nilai histogram sendiri-sendiri berdasarkan nilai yang dihasilkan dalam perhitungan gradien yang kemudian dilakukan normalisasi pada setiap blok. Cell memiliki ukuran 8x8 piksel pada sebuah citra. Sedangkan blok memiliki ukuran $2 \times 2$ cell. Ilustrasi ditunjukkan pada Gambar 2.

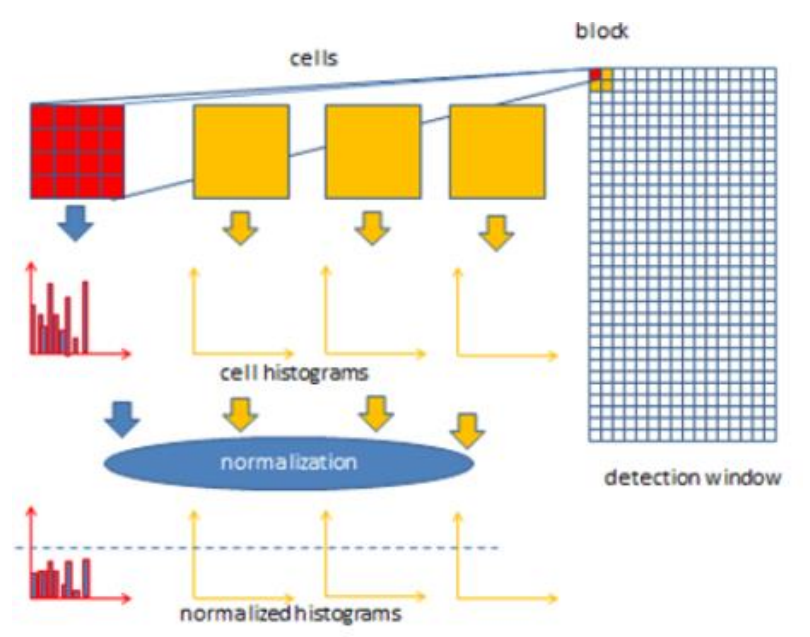

Gambar 2. Cell yang menyusun sebuah blok

Nilai normalisasi fitur blok didapat dari (4). Fitur blok dinormalisasi untuk mengurangi efek perubahan kecerahan obyek pada satu blok. Variabel $b$ merupakan nilai blok fitur dan variabel $e$ merupakan bilangan positif yang bernilai kecil untuk mencegah pembagian dengan 0 .

$b=\frac{b}{\sqrt{b^{2}+e}}$

Nilai normalisasi tiap blok digabungkan menjadi satu vektor menjadi fitur vektor HOG. Kemudian fitur vektor HOG dilakukan normalisasi. Normalisasi dilakukan melalui (5). Variabel $h$ merupakan nilai fitur HOG dan variabel $e$ merupakan bilangan positif yang bernilai kecil untuk mencegah pembagian dengan 0 .

$$
h=\frac{h}{\sqrt{\left.\|h\|\right|^{2}+e}}
$$

\section{B. Hierarchical centroid}

Metode Hierarchical Centroid adalah deskriptor sederhana dengan mendapatkan pusat massa dari suatu obyek. Pusat massa pada bentuk sederhana seperti persegi, lingkaran, dan segitiga mudah didapatkan dan sederhana untuk menghitungnya. Namun, untuk mendapatkan pusat massa pada bentuk yang tidak beraturan sulit didapatkan dan perhitungan lokasinya sulit. Oleh karena itu, untuk mendapatkan pusat massanya dilakuakn dengan menghitung jarak rata-rata di setiap arah dan menyatakan proporsi dari total luas obyek. Setiap titik pada perubahan ukuran bentuk dikenal sebagai moment [5].

Gambar 3 menunjukkan centroid dari area citra dimana $\mathrm{f}(\mathrm{x})$ dan $\mathrm{g}(\mathrm{x})$ berbentuk kurva. Untuk menghitung nilai pusat massanya pertama-tama hitung luas bidang dari obyek dihitung menggunakan (6).

$$
A=\int_{a}^{b}[f(x)-g(x)] d x
$$




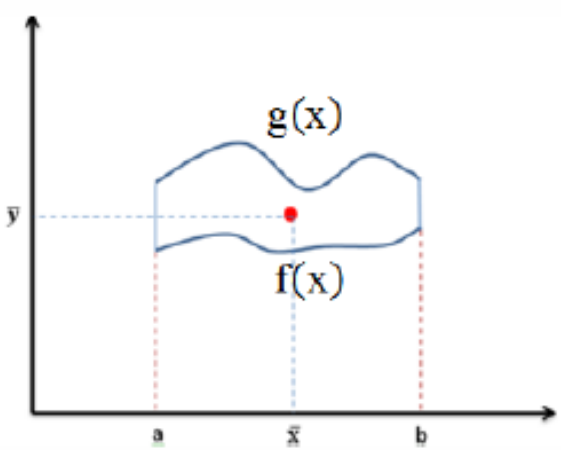

Gambar 3. Centroid pada suatu bidang

Variabel $A$ merupakan luas bidang pada obyek. Sedangkan variabel $a$ merupakan batas minimal dari obyek pada sumbu- $x$ dan variabel $b$ merupakan batas maksimal dari obyek pada sumbu- $x$. Nilai $a$ dan $b$ diilustrasikan pada Gambar 3. Nilai centroid dari suatu obyek dapat direpresentasikan sebagai $x$ dan $y$ diperoleh dari (7).

$x=\frac{1}{A} \int_{a}^{b}[x(f(x)-g(x))] d x$

$y=\frac{1}{A} \int_{a}^{b} \frac{1}{2}\left[x\left(f(x)^{2}-g(x)^{2}\right)\right] d x$

\section{SKETCH BASED IMAGE RETRIEVAL}

\section{A. Desain Sistem}

Pada bagian ini merupakan desain sistem dari pencarian gambar berbasis sketsa. Input berupa sketsa gambar yang akan dicari kemiripannya dengan gambar yang ada dalam dataset. Gambar yang ada pada dataset terdiri dari 10 kelas gambar yaitu, bintang laut, menara Big Ben, menara Burj Al-arab, sepeda, London Eye, gerbang Arc de Triomphe, Piramida Mesir, gedung Sydney Opera, jembatan Sydney, pantai. Gambar pada dataset dan gambar sketsa dilakukan preprosessing untuk mencari tepi gambar dan menjadikan gambar menjadi gambar binary. Metode yang digunakan pada tahap preprocessing adalah metode Sobel, ditunjukkan pada gambar 4.

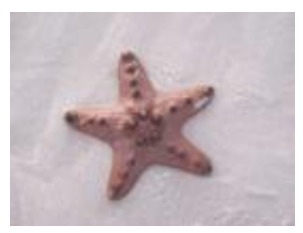

(a)

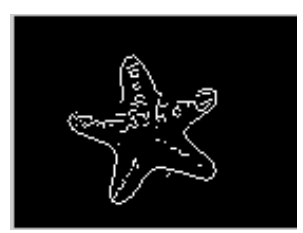

(b)
Gambar 4. Hasil Preprocessing (a) Citra RGB (b) citra yang telah dideteksi tepi dengan Sobel

Kemudian dilakukan ekstraksi fitur dan diukur jarak kedekatannya lalu ditampilkan gambar yang jarak kedekatannya paling kecil. Ekstraksi fitur yang digunakan adalah Histogram of Oriented Gradient (HOG) dan Hierarchical Centroid. Kedua ekstraksi fitur ini berdasarkan pada bentuk gambar. Metode HOG merupakan fitur untuk mencari orientasi dari gambar, sedangkan metode Hierarchical Centroid mencari nilai centroid secara hierarki. Ekstraksi fitur dilakukan pada dataset gambar dan gambar sketsa. Selanjutnya dilakukan pengukuran jarak kedekatan antara dataset gambar dan gambar sketsa menggunakan euclidean distance. Setelah itu dilakukan pengurutan secara ascending. Hasil akhir dari program ini adalah menampilkan sejumlah gambar yang memiliki nilai similarity kecil. Diagram alir proses ini ditunjukkan pada Gambar 5.

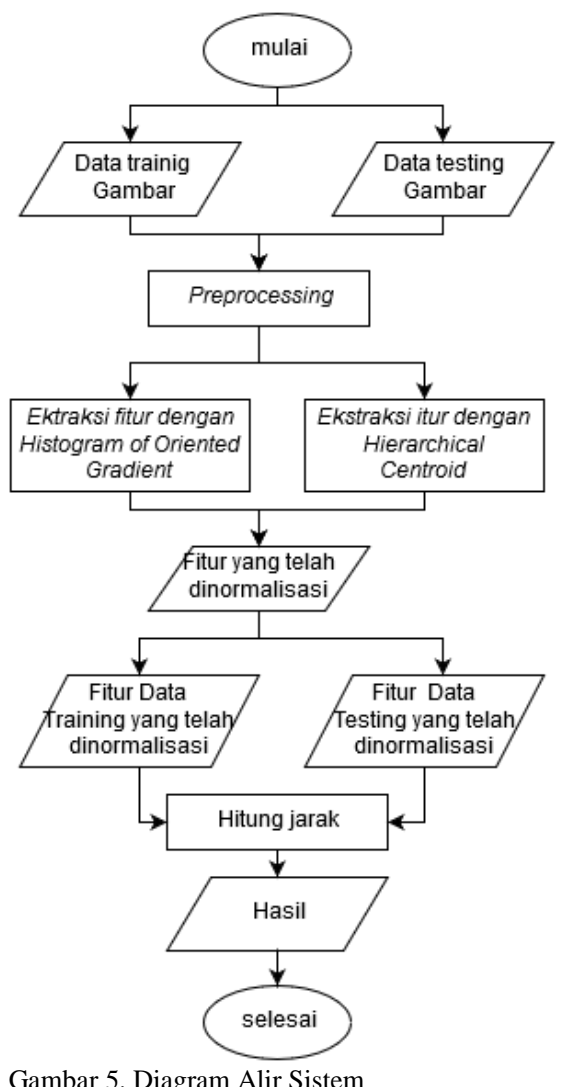

Pada Gambar 5, ukuran gambar dari data testing dan data training adalah 134 x 100 piksel. Untuk metode HOG ukuran cell yang digunakan adalah $8 \times 8$ piksel dan blok $2 \times 2$ cell. Ukuran bin histogram berjumlah 9 dalam sudul 180 derajat. Penentuan nilai histogram dilakukan dengan melakukan voting terhadap masing-masing cell pada citra. Voting dilakukan dengan metode bi-linear inerpolation di mana nilai yang saling overlapping akan dilakukan normalisasi. Untuk metode Hierarchical Centroid langkah dalam melakukan ekstraksi fitur dengan Hierarchical Centroid adalah yang pertama citra input berupa citra hitam putih dihitung luas area yang digunakan pada perhitungan centroid, kemudian hitung nilai centroid pada sumbu x. Setelah itu citra dibagi menjadi citra sebelah kanan dan citra sebelah kiri lakukan rekursif untuk mencari nilai centroid. Rekursif berhenti jika telah mencapai kedalaman yang telah ditentukan. Setelah mendapatkan titik-titik centroid yang merupakan fitur dari Hierarchical Centroid, kemudian fitur dilakukan normalisasi untuk menghilangkan nilai yang lebih dominan.

\section{B. Data Training}

Data trainining merupakan kumpulan gambar yang digunakan untuk melatih sistem agar dapat mengeluarkan hasil yang sesuai. Gambar data training didapat dari Centre for Vision, Speech and Signal Processing, University of Surrey, 
United Kingdom [8] yang terdiri dari 1000 gambar dari 10 kelas yang berbeda. Setiap kelasnya terdiri dari 100 gambar. Kesepuluh kelas yaitu, bintang laut, menara Big Ben, menara Burj Al-arab, sepeda, London Eye, gerbang Arc de Triomphe, Piramida Mesir, gedung Sydney Opera, jembatan Sydney, pantai. Contoh data training ditunjukkan pada Gambar 6.
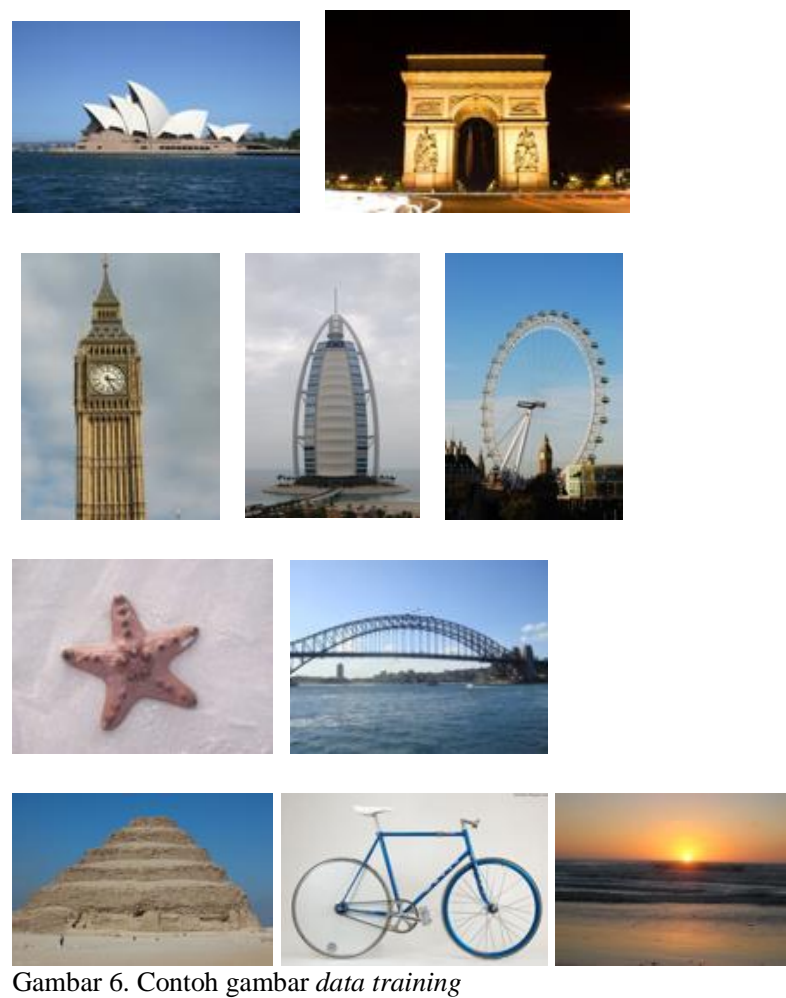

Gambar 6. Contoh gambar data training

\section{Data Testing}

Data testing merupakan kumpulan gambar yang digunakan untuk melakukan pengujian terhadap sistem. Data testing yang digunakan berjumlah 30 gambar dari 10 kelas. Masing-masing kelas terdiri dari 3 gambar. Data testing didapat dari hasil sketsa gambar secara manual. Contoh gambar data testing ditunjukkan pada Gambar 7.
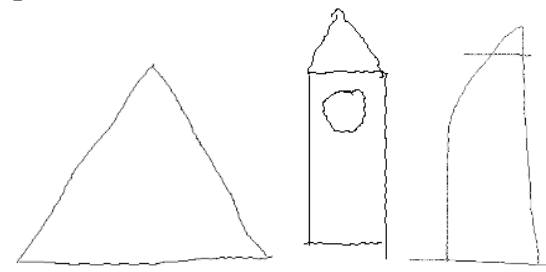

Gambar 7. Contoh gambar data testing

\section{HASIL DAN EVALUASI}

\section{A. Pengujian dengan berbagai kedalaman centroid}

Pada pengujian melakukan perhitungan nilai performa dengan metode Histogram of Oriented Gradients dan Hierarchical Centroid dengan kedalaman hierarki 2, 3, 4, 5, dan 6. Performa yang dihitung adalah nilai Average Normalized Modified Retrieval Rank (ANMRR), nilai presisi, recall dan nilai akurasi. Setiap kedalaman diuji pada 30 queri data testing. Perhitungan nilai ANMRR dilakukan dengan langkah sebagai berikut [9]. Langkah pertama mencari nilai rata-rata ranking dari banyaknya queri dapat dicari dari (8).

$$
A V R(q)=\sum_{k=1}^{N G(k)} \frac{\operatorname{Rank}(k)}{N G(q)}
$$

Di mana variabel $A V R$ merupakan nilai rata-rata rangking pada queri ke- $q, N G(q)$ adalah jumlah ground thruth gambar pada queri ke-q. Jika citra yang ditampilkan terdapat pada $K$ yang pertama maka $\operatorname{Rank}(k)=R$, jika tidak $\operatorname{Rank}(k)=1,25 * K$. Variabel $R$ adalah rangking citra pada $K$ pertama yang ditampilkan. $K$ adalah top-rangking yang ditampilkan. Di mana nilai $K$ dapat diperoleh dari (9).

$$
K(q)=\min \{X * N G(q), X * G M T\}
$$

Jika $N G(q)>50$ maka $X=2$ jika lebih dari 50 maka $X=4$. Parameter $X$ didefinisikan oleh MPEG-7. GMT merupakan nilai maksimum ground truth untuk semua queri didalam dataset.

Kemudian mencari nilai modified retrieval rank $(\operatorname{MRR}(q))$, diperoleh dari (10).

$$
\operatorname{MRR}(q)=A V R(q)-0.5 \times(1+N G(q))
$$

Melakukan normalisasi pada ranking retrieval $(N M R R(q))$ agar data tidak ada yang dominan. Normalisasi didapat dari (11).

$$
\operatorname{NMRR}(q)=\frac{\operatorname{MRR}(q)}{1.25 \times K-0.5 \times(1+N G(q))}
$$

Langkah terakhir dihitung nilai rata-rata dari normalisasi semua queri atau nilai ANMRR. Dihitung dengan (12).

$$
A N M R R=\frac{1}{Q} \sum_{q=1}^{Q} \operatorname{NMRR}(q)
$$

$Q$ adalah banyaknya queri yang diujikan. Nilai $N M R R$ dan $A N M R R$ memiliki rentang nilai di antara $[0,1]$, di mana semakin kecil nilai NMRR dan ANMRR berarti performa dari metode tersebut lebih bagus.

Tabel 1.

\begin{tabular}{cc}
\multicolumn{2}{c}{ Nilai ANMRR pada kedalaman yang berbeda } \\
\hline Kedalaman Centroid & Nilai ANMRR \\
\hline 2 & 0,474 \\
$\mathbf{3}$ & $\mathbf{0 , 3 5 2}$ \\
4 & 0,374 \\
5 & 0,412 \\
6 & 0,439
\end{tabular}

Berdasarkan hasil yang ditunjukkan pada Tabel 1 menunjukkan bahwa pada kedalaman 3 menghasilkan nilai ANMRR yang paling baik yaitu 0,352. Sedangkan pada kedalaman 2 menghasilkan nilai ANMRR 0,474. Pada kedalaman 4 menghasilkan nilai 0,374 , pada kedalaman 5 menghasilkan nilai 0,412 dan pada kedalaman 6 menghasilkan nilai 0,439 . Hal ini menunjukkan bahwa letak centroid yang paling baik ada pada kedalaman 3. Sehingga semakin tinggi kedalamannya letak centroidnya semakin tidak akurat, banyak letak centroid-nya yang melebihi dari gambar obyek. Sehingga pada kedalaman 3 menampilkan letak centroid yang lebih bak dari pada kedalaman yang lain. 
Perhitungan performa presisi, recall, dan akurasi didapat dari tabel confussion matrix yang terbentuk [10]. Nilai presisi, recall, dan akurasi dapat dihitung dari (13), (14) dan (15).

$$
\begin{aligned}
& \text { Presisi }=\frac{T P}{T P+F P} \\
& \text { Recall }=\frac{T P}{T P+F N} \\
& \text { Akurasi }=\frac{T P+T N}{T P+T N+F P+F N}
\end{aligned}
$$

Nilai $T P, T N, F \mathrm{P}$ dan $F N$ didapat dari tabel confussion matrix yang merupakan True Positive, True Negative, False Positive, dan False Negative.

Tabel 2.

Nilai presisi, recall, dan akurasi pada kedalaman yang berbeda

\begin{tabular}{cccc}
\hline \hline Kedalaman & Presisi & Recall & Akurasi \\
\hline 2 & 0,731 & 0,731 & 0,939 \\
$\mathbf{3}$ & $\mathbf{0 , 7 8 5}$ & $\mathbf{0 , 7 8 5}$ & $\mathbf{0 , 9 5 7}$ \\
4 & 0,779 & 0,779 & 0,956 \\
5 & 0,762 & 0,762 & 0,952 \\
6 & 0,756 & 0,756 & 0,951 \\
\hline \hline
\end{tabular}

Dari Tabel 2 dapat dilihat bahwa nilai presisi, recall dan akurasi yang paling tinggi terdapat pada kedalaman 3 sebesar 0,785 untuk presisi dan recall serta 0,957 untuk akurasi. Nilai presisi dan recall sama karena jumlah gambar yang ditampilkan ada 100 gambar dan jumlah gambar setiap kelas ada 100 gambar. Untuk rincian nilai presisi, recall dan akurasi pada masing-masing queri ditampilkan pada lampiran halaman 73. Hal ini menunjukkan bahwa nilai presisi, recall dan akurasi sebanding dengan nilai ANMRR. Semakin bagus nilai ANMRR maka nilai presisi, recall dan akurasi juga akan semakin bagus.

\section{B. Perbandingan dengan metode lain}

Perbandingan dengan metode lain dilakukan dengan cara melakukan perhitungan nilai Average Normalized Modified Retrieval Rank (ANMRR) dan perhitungan nilai presisi, recall dan akurasi dengan metode Histogram of Oriented Gradients dan Hierarchical Centroid, metode Histogram of Oriented Gradients, metode Region properties, dan Edge of Histogram Descriptor. Uji coba ini dilakukan untuk membandingkan apakah metode HOGHC lebih baik dari metode lainnya. Tabel 3 dan Tabel 4 menampilkan nilai performa dari masing-masing metode.

Tabel 3.

Nilai ANMRR pada masing-masing metode

\begin{tabular}{cc}
\hline \hline Metode & Nilai ANMRR \\
\hline EHD & 0,88 \\
HOG & 0,45 \\
RP & 0,92 \\
HC & 0,74 \\
HOGHC & $\mathbf{0 , 3 5}$ \\
\hline \hline
\end{tabular}

Tabel 4.

Nilai presisi, recall, dan akurasi pada masing-masing metode

\begin{tabular}{cccc}
\hline \hline Metode & Presisi & Recall & Akurasi \\
\hline EHD & 0,32 & 0,32 & 0,43 \\
HOG & 0,69 & 0,69 & 0,81 \\
RP & 0,29 & 0,29 & 0,36 \\
\hline
\end{tabular}

\begin{tabular}{cccc}
\hline HC & 0,41 & 0,41 & 0,52 \\
HOGHC & $\mathbf{0 , 7 8}$ & $\mathbf{0 , 7 8}$ & $\mathbf{0 , 9 6}$ \\
\hline \hline
\end{tabular}

Pada Tabel 3 terlihat bahwa nilai ANMRR paling kecil terdapat pada metode kombinasi Histogram of Oriented Gradient dan Hierarchical Centroid sebesar 0.52. Sedangkan pada metode Edge of Histogram Descriptor nilai ANMRR sebesar 0.88, pada metode Histogram of Oriented Gradients sebesar 0.58, Region Properties sebesar 0.92 dan metode Hierarchical Centroid sebesar 0,74. Hal ini menunjukkan bahwa menggunakan metode HOGHC dapat menghasilkan perankingan lebih baik dari metode lain yang umumnya digunakan pada permasalahan Sketch Based Image Retrieval. Sedangkan pada Tabel 4 terlihat bahwa nilai presisi, recall, dan akurasi tertinggi terdapat pada metode HOGHC, sehingga HOGHC lebih baik digunakan dalam pencarian gambar berbasis sketsa dari pada metode-metode yang lainnya seperti Histogram of Oriented Gradient, Edge of Histogram Descriptor, Region Properties, dan Hierarchical Centroid. Gambar 8 menampilkan keluaran dari program.

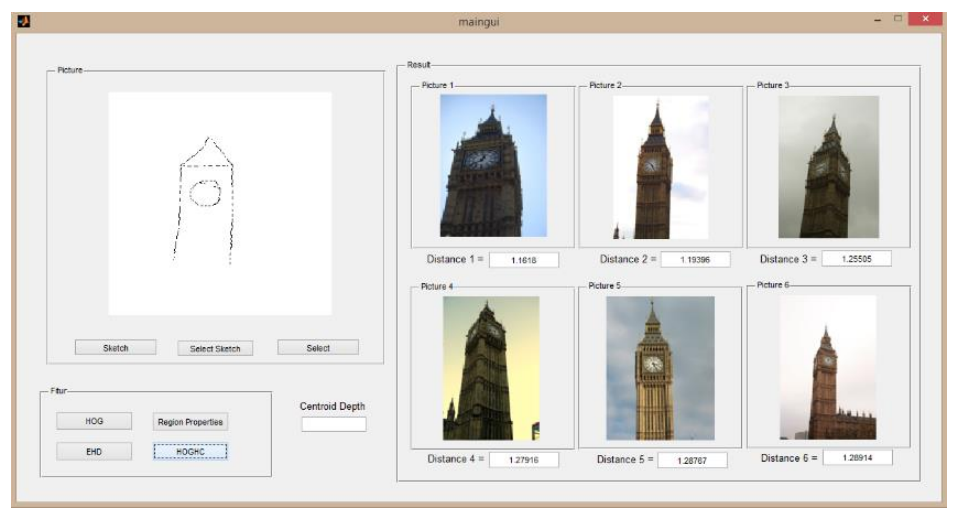

Gambar 8. Hasil keluaran program

\section{KESIMPULAN}

Kesimpulan yang didapatkan berdasarkan hasil uji coba pencarian gambar dengan metode kombinasi Histogram of Oriented Gradients dan Hierarchical Centroid adalah dengan implementasi preprocessing menggunakan metode Sobel menghasilkan hasil yang kurang bagus karena ada bagian tepi yang tidak terdeteksi sebagai tepi dan masih terdapat noise sehingga mengganggu dalam proses ekstraksi fitur. Hal tersebut terjadi khususnya pada gambar data training. Sedangkan implementasi metode kombinasi Histogram of Oriented Gradient dan Hierarchical Centroid dapat digunakan sebagai metode dalam pencarian gambar berbasis sketsa. Kedalaman nilai centroid yang baik digunakan yang menghasilkan nilai ANMRR, presisi, recall dan akurasi yang terbaik ada pada kedalaman 3. Nilai ANMRR pada kedalaman 3 sebesar 0,35. Sedangkan rata-rata nilai presisi dan recall sebesar 0,78 . Serta nilai akurasi tertinggi sebesar 0,96. Metode kombinasi Histogram of Oriented Gradients dan Hierarchical Centroid menghasilkan nilai ANMRR, presisi, recall, dan akurasi lebih baik dari pada metode lainnya yang diuji seperti metode Histogram of Oriented Gradients, Hierarchical Centroid, Edge Histogram Descriptor dan Region Properties. 


\section{DAFTAR PUSTAKA}

[1] J. M. Saavedra dan B.Bustos, "An improved histogram of edge local orientations for sketch-based image retrieval," Pattern Rocognition, pp. 432-441, 2010.

[2] J. P. Eakins, "Trademark image retrieval," dalam S.W. Lew (Ed), Principle of visual Information Retrieval, New York, Springer, 2001, pp. 319-354.

[3] T. Kato, T. Kurita, N. Otsu dan K. Hirata, "A sketch retrieval method for full color image database-query by visual example," dalam Proc. of the 11th IAPR International Conf on Computer Vision and Applications, 1992.

[4] A. K. Jain dan A. Vailaya, "A case study with trademark image databases," Pattern recognition, vol. 31, no. 9, pp. 1369-1390, 1998.

[5] N. M. Asiri, N. AlHumaidi dan N. AIOsaim, "Combination of Histogram of Oriented Combination of Histogram of Oriented Sketch-Based Image Retrieval," 2015.

[6] R. Hu, M. Barnard, and J. P. Collomosse, "Gradient field descriptor for sketch based retrieval and localization," in ICIP, 20 I 0, pp. 1025-1028.

[7] N. Dalal dan B. Triggs, "Histograms of Oriented Gradients for Human Detection," dalam one-Alps, 655 avenue de l'Europe, Montbonnot 38334, France, 2005.

[8] R. Hu dan J. Collomosse, "A Performance Evaluation of Gradient Field HOG Descritpor for Sketch Based Image Retrieval," Computer Vision and Image Understanding (CVIU), 2013.

[9] MPEG-7, "Subjective Evaluationof the MPEG-7 Retrieval Accuracy Measure (ANMRR)," 2000.

[10] J. R. Taylor, "An Introduction to Error Analysis: The Study of Uncertainties in Physical Measurements," dalam University Science Books, 1999, pp. 128-129. 